\title{
EFFECT OF WTO LAW IN THE EU \\ AND THE INDIVIDUAL'S RIGHT TO DAMAGES CAUSED BY A BREACH OF WTO LAW
}

\begin{abstract}
Ivana Živičnjak*
Summary: The question of the legal status and effect of WTO law within the EU legal order is a controversial issue. For years the ECJ has firmly held the position that due to its nature and structure the WTO Agreement is not capable of having direct effect and does not in principle form part of the European courts' legality review. At the same time, there are also fierce debates among scholars about what kind of effect WTO law should have in the EU legal order. This paper analyses what kind of impact granting direct effect to the WTO Agreement would have on EU institutions and the EU in general, whether this could harm the EU and if there are some negative consequences, would the benefits arising outweigh the costs. Consideration is ultimately given to whether the WTO Agreement should be granted direct effect. Further, the paper analyses the possibilities for individuals to obtain compensation for damage caused by a breach of WTO law and stresses the need to increase the current level of judicial protection for individuals who have suffered great damage as incidental victims affected by retaliation resulting from a WTO dispute. Finally, given the present circumstances of the WTO system, the most appropriate solution to these issues is offered.
\end{abstract}

\section{Introduction}

The question of the legal status and effect of WTO law within the EU legal order is a controversial issue. For years there have been fierce debates among scholars, and various opinions have been given about what kind of effect WTO law has and should have in the EU legal order. The idea of granting direct effect to the WTO Agreement ${ }^{1}$ has both its advocates and bitter opponents and there are also supporters of some kind of middle ground. The issue of the direct effect of the WTO Agreement is relevant because, as the EU is bound by WTO law, traders count in their international operations on the rights granted to them under the WTO

\footnotetext{
* Trainee lawyer. I wish to express my deep gratitude to my mentor Prof Dr Tamara Perišin for her support and guidance during the final year of my studies at the Faculty of Law, University of Zagreb, as well as in the writing of this paper.

1 Agreement Establishing the World Trade Organization (WTO), Marrakesh, 15 April 1994.
} 
and in the case of a breach of WTO law perpetrated by the EU, due to a lack of direct effect, they cannot protect their interests before the courts. They are thus prevented from the enforcement of rights to which they consider they are entitled. An especially burning issue is the situation where traders suffer damage as victims of retaliation which is a consequence of the EU's delay in complying with WTO law after inconsistency has been found with its measures.

In this paper an attempt will be made to answer questions about whether the WTO Agreement should be granted direct effect and whether individuals can obtain compensation for damage caused by a breach of WTO law. Therefore, the analysis will consider basic principles, fundamental provisions and findings of the Court of Justice of the European Union concerning the relationship of EU law and international law in general. It is also necessary to analyse the Court of Justice's reasoning in answering the above questions. Is not granting direct effect to the WTO Agreement really justifiable and the right thing to do? Could giving direct effect to WTO law harm the EU? Consideration will also be given to the current level of judicial protection for individuals.

The analysis will examine the arguments for and against granting direct effect. The intention is to decide whether this would be an acceptable solution for individuals who have been damaged and for the EU in general, or whether some other solution should be found. In this paper, a solution that seems most appropriate given the present circumstances of the WTO system will be offered.

\section{Defining the grounds}

The term 'direct effect' was first used by the European Court of Justice (ECJ) when it attributed to specific Treaty articles the legal quality of 'direct effect' in the van Gend en Loos case ${ }^{2}$ in 1963. It applies to those aspects of EU law that are enforceable directly by EU citizens in their own Member State, regardless of whether the Member State has introduced specific national laws to implement the provisions. In essence, it permits individual citizens to enforce the legal rights conferred on them by EU law entirely independent of national law. So, we can say that direct effect is here to make life easier for individual citizens. In van Gend en Loos, the ECJ identified three conditions necessary to establish the direct effect of primary EU law. ${ }^{3}$ The first is that the provision must

\footnotetext{
2 Case 26/62 NV Algemene Transporten Expeditie Onderneming van Gend en Loos v Nederlandse Administratie der Belastingen [1963] ECR 1.

3 ibid, para 12.
} 
be sufficiently clear and precisely stated. ${ }^{4}$ Second, it must be unconditional and not dependent on any other legal provision. ${ }^{5}$ And third, it must confer a specific right upon which a citizen can base a claim. ${ }^{6}$ Over the years, the jurisprudence of the ECJ has established a number of tests in order to determine whether a provision is capable of direct effect and these initial conditions have been broadened and loosened. In 1963, only the Treaty provisions could have the legal quality of direct effect, but nowadays this applies in principle to all binding EU law, including EU Treaties, secondary legislation (regulations, directives and decisions) and, in certain cases, international agreements.

In answering the question whether the WTO Agreement is capable of direct effect, one should bear in mind that this legal quality was developed in relation to EU law and that international agreements have a slightly different status. So, before dealing further with the question of the direct effect of WTO law in the European legal order, it is necessary to analyse the grounds - the basic principles, fundamental provisions and findings of the ECJ - upon which further analysis can be built. Thus, we shall give a brief outline of how the ECJ handles the invocability of international agreements ${ }^{7}$ in general before taking into consideration how the World Trade Organization itself oversees the application of its law. Next, we shall identify the general consequences of not complying with WTO provisions, and then explain why the question of the direct effect of WTO law is even relevant.

\subsection{Invocability of international agreements in general}

The European Treaties do not determine the relationship between EU law and international law in a detailed manner. In the Treaty on the

\footnotetext{
4 ibid.

5 ibid.

6 ibid.

7 There is academic and judicial uncertainty about the exact meaning of the terms 'direct effect', 'invocability of international agreements' and 'direct applicability'. See Paul Craig and Gráinne de Búrca, EU LAW: Lex, Cases and Material (OUP 2008) 269. It has to be mentioned that the ECJ has used these concepts without any legal distinction. In this paper, however, these concepts are distinguished: invocability is a concept wider than direct effect; it implies the ability of a legal subject to rely on the provision of an international agreement. If an international agreement is invocable, it can be used as a criterion for the legality review of Union acts. Direct effect is thus a sub-category of invocability and it has meaning only in relation to individuals. See Rass Holdgaard, External Relations Law of the European Community: Legal Reasoning and Legal Discourses (Kluwer Law International 2008) 244; Case C-149/96 Portugal $v$ Council [1999] ECR I-8395, Opinion of AG Saggio, para 18. Direct applicability implies that no Union act is necessary for an international agreement to become part of EU law. See Alina Kaczorowska, European Union Law (Routledge-Cavendish 2008) 297; Jan Winter, 'Direct Applicability and Direct Effect: Two Distinct and Different Concepts in Community Law (1972) 9 CML Rev 425.
} 
Functioning of the European Union (TFEU) ${ }^{8}$ there are very few provisions on international agreements. The fundamental provision determining that relationship is article 216(2) TFEU (ex article 300(7) TEC). Pursuant to this provision, agreements concluded by the EU are binding upon the institutions of the EU and upon its Member States. From this, the ECJ drew the conclusion that once it has entered into force an international agreement forms an integral part of the Union's legal order. ${ }^{9}$ In addition, from the wording of article 218(11) TFEU (ex Article 300(6) TEC), ${ }^{10}$ the hierarchical position of international agreements in the EU legal order can be concluded. The article indicates that they do not prevail over EU primary law, so the logical conclusion is that they rank between primary and secondary law. This has been confirmed by the ECJ - first implicitly $^{11}$ and eventually explicitly. ${ }^{12}$ By looking at these provisions, one can easily conclude that the provisions of international agreements must be obeyed. So, if the infringement of an international agreement by Union secondary legislation occurs, this could be a ground for finding acts of the institutions invalid, although things are little more complicated than this. Treaties remain silent on the effects of international law in the EU legal order or on how international law should enter the EU legal order. In the absence of legislative regulation, it is up to the ECJ to determine the relationship between international and EU law. To analyse the relationship between international law and EU law we can analogously apply principles that govern the relationship between international law and domestic law. ${ }^{13}$ This relationship can be governed in two ways: a state can choose between monism and dualism. Under monism, international law becomes part of the national legal order without formal transformation. Under dualism, international law has to be formally transformed into domestic law. Monism can be seen as favouring international law, while dualism protects the sovereignty of the state. In assessing the relationship between international and EU law, the ECJ has applied both monism and dualism, ie different international agreements have different

\footnotetext{
8 Consolidated version of the Treaty on the Functioning of the European Union [2008] OJ C115 of 9 May 2008 (hereinafter TFEU).

9 Case 181/73 Haegeman [1974] ECR 449 para 5; Case 104/81 Hauptzollamt Mainz/Kupferberg [1982] ECR 3641, paras 11-14 (hereinafter Kupferberg).

10 Art 218(11) TFEU (ex art 300(6) TEC). A Member State, the European Parliament, the Council or the Commission may obtain the opinion of the Court of Justice as to whether an agreement envisaged is compatible with the Treaties. Where the opinion of the Court is adverse, the agreement envisaged may not enter into force unless it is amended or the Treaties are revised.

11 Case 40/72 Schróeder KG v Germany [1973] ECR 125, para 13.

12 Case C-344/04 International Air Transport Association and European Low Fares Airline Association v Department for Transport [2006] ERC I-403, para 35.

13 See John H Jackson, 'Status of Treaties in Domestic Legal Systems: A Policy Analysis' 86(2) American Journal of International Law 310.
} 
legal status in the EU legal order. ${ }^{14}$ Whether an individual can invoke an international agreement before a national court or the ECJ to question the validity of Union secondary law depends on whether that agreement has direct effect. If the issue of direct effect is not settled within the agreement, the task of determining whether the agreement has direct effect lies with the ECJ. ${ }^{15}$ In the Kupferberg judgment, ${ }^{16}$ the ECJ examined the direct effect of a provision of the Free Trade Agreement concluded between the European Economic Community and Portugal. The ECJ first established that it can rule on such a matter only if the effect of the agreement in the internal legal order of the parties is not settled in the agreement itself. ${ }^{17}$ Then it examined the intention of the parties and concluded that they had not intended to preclude the agreement from having direct effect. After that, the ECJ applied its two-tier approach: first, it analysed whether the invoked provision was unconditional and sufficiently clear to have direct effect;18 and secondly, it analysed the wording, purpose and nature of the agreement in its entirety in order to determine whether the overall agreement contradicted the findings on the direct effect of the specific provision. ${ }^{19}$ The ECJ concluded that the provision had direct effect. An important fact that must be kept in mind is that in Kupferberg no Community measure had been challenged. With the granting of direct effect to the Free Trade Agreement, the scope of Community law was expanded! In Demirel, the ECJ clarified the conditions for direct effect from its Kupferberg judgment by stating:

A provision in an agreement concluded by the Community with nonmember countries must be regarded as being directly applicable when, in regard to its wording and the purpose and nature of the agreement itself, the provision contains a clear and precise obligation which is not subject, in its implementation or effects, to the adoption of any subsequent measure. ${ }^{20}$

So, it can be seen that the test of direct effect of international agreements is much stricter than the test of direct effect for EU law in general. The ECJ has so far granted direct effect to several provisions of bilateral agreements which were, in the eyes of the Court, clearly designed to

\footnotetext{
14 See below, in particular part 3.

15 See Cases 21 to 24/72 International Fruit Company [1972] ECR 1219, para 19 and Kupferberg (n 9) para 17.

16 Kupferberg (n 9).

17 ibid, para 17.

18 ibid, para 23.

19 ibid, para 23.

20 Case 12/86 Demirel v Stadt Schwaebisch Gmund [1987] ECR 3719, para 14.
} 
grant rights to individuals. ${ }^{21}$ As regards the WTO Agreement, the current view of the ECJ is that the WTO Agreement does not satisfy the conditions for direct effect. ${ }^{22}$

Generally, there are four procedural routes available for individuals to invoke an international agreement, including the WTO Agreement, before the ECJ. The first remedy is an action for annulment under article 263 TFEU (ex Article 230 TEC) according to which an individual may request the ECJ to review the legality of an act of Union institutions if the act is of direct and individual concern to them. If the ECJ finds the measure to be unlawful, that measure will be annulled. The second remedy is an action for failure to act under article 265 TFEU (ex article 232 TEC) against inaction by the EU institutions if an individual can establish that the EU institution has failed to address to him any act other than a recommendation or an opinion. The third remedy is an action for damages under article 340(2) TFEU (ex article 288(2) TEC) which states:

In the case of non-contractual liability, the Union shall, in accordance with the general principles common to the laws of the Member States, make good any damage caused by its institutions or by its servants in the performance of their duties.

And fourth, an alternative route for individuals to invoke an international agreement before the ECJ is to raise the question of the validity of acts of Union institutions before the national court which will then, under article 267 TFEU (ex article 234 TEC), request the ECJ to give a preliminary ruling on that subject. In article $263 \mathrm{TFEU}$, it is stated that the ECJ shall review legality on grounds of lack of competence, infringement of an essential procedural requirement, infringement of the Treaties or of any rule of law relating to their application, or misuse of powers. According to article 265 TFEU, the ECJ shall establish if there was an infringement of the Treaties. As regards article 340(2) TFEU, it must be established what the 'general principles common to the laws of the Member States' are. It seems that, in order to obtain compensation from the Union, one of the key requirements is that the damage must be a consequence of an unlawful act, but it should be mentioned that there are some national laws on non-contractual liability which allow individuals to obtain compensation even in the absence of unlawful ac-

\footnotetext{
${ }_{21}$ For example, art 2(1) Yaounde Convention 1963 (Case 87/75 Bresciani [1976] ECR 129); art 21(1) EEC - Portugal Free Trade Agreement (Case 104/81 Hauptzollamt Mainz $v$ CA Kupferberg \& Cie KG aA [1982] ECR 3641); art 6 EEC - Sweden Agreement (Case C-163/90 Administration des douanes et droits indirects $v$ Legros [1992] ECR I-4625); art 18(1) EEC - Austria Free Trade Agreement (Case C-312/91 Metalsa Srl v Italy [1993] ECR I-3751).

22 See part 3 below.
} 
tion. ${ }^{23}$ So, according to these provisions of the TFEU, individuals who seek to invoke the provisions of the WTO Agreement may benefit from these four procedural routes only if (apart from the requirement of direct effect) the WTO Agreement is among the rules in the light of which the ECJ reviews the legality of acts of the Union institutions. Pursuant to current ECJ case law, WTO law does not in principle form part of the European courts' legality review, ${ }^{24}$ so these procedural routes can have no positive outcome for individuals (or any other applicant). It seems that the ECJ's conclusion that 'once it has entered into force, an international agreement forms an integral part of the Union's legal order'25 is without legal relevance.

\subsection{A view from the WTO standpoint}

According to article XVI (4) of the Agreement establishing the World Trade Organization (WTO) with respect to national law, each Member shall ensure the conformity of its laws, regulations and administrative procedures with its obligations as provided in the annexed Agreements'. At first sight, this provision seems to be formulated quite weakly, but if we take into consideration provisions of general public international law we can conclude that this provision is formulated much more strictly than is required under general international law provisions. Article 26 of the Vienna Convention on the Law of Treaties (VCLT) ${ }^{26}$ headed 'Pacta sunt servanda' prescribes that 'every treaty in force is binding upon the parties to it and must be performed by them in good faith'. Article $27 \mathrm{VCLT}^{27}$ entitled 'Internal law and observance of treaties' lays down that 'a party may not invoke the provisions of its internal law as justification for its failure to perform a treaty'. While these general rules only mention performing a treaty in good faith and the inability to justify non-performance by internal law, article XVI (4) WTO lays down for member states the obligation of having their legal order in conformity with the WTO provisions. Still, this article cannot compel domestic courts to review the legality of national law with regard to the WTO provisions and it especially cannot compel them to do so at the request of an individual. This depends only on the preference of the member state. Most of the WTO member states, among whom are the United States, Canada, Japan and China - some of the major players in the world trade system - did not grant WTO law direct effect in their

\footnotetext{
23 See Christian von Bar, Non-Contractual Liability Arising out of Damage Caused to Another (Principles of European Law, vol 7, OUP and Staempfli Publishers 2009).

24 See part 3 below.

25 Haegeman (n 9); Kupferberg (n 9).

26 Vienna Convention on the Law of Treaties (VCLT), Vienna, 23 May 1969.

$27 \operatorname{VCLT}(\mathrm{n} 26)$.
} 
legal order and are not fond of such an idea. ${ }^{28}$ Even the WTO panel has explicitly established that WTO law does not have direct effect and stated that it would be more 'convenient to speak of the principle of indirect effect'. ${ }^{29}$ Thus, the only consequence for a WTO member state (which has not granted WTO law direct effect) for not having its legal order in conformity with WTO law lies within the organisation.

A member state which considers itself to be damaged by a breach of WTO law perpetrated by another member state may initiate a dispute settlement procedure provided in the Understanding on the Rules and Procedures Governing the Settlement of Disputes in the World Trade Organization (DSU). ${ }^{30}$ Here, we have to emphasise that individuals have no access to this procedure. The procedure is formally initiated by a request of the complaining member state for consultations where the aim is to achieve a mutually agreed solution. If a mutually agreed solution is not achieved, the complaining party may request the establishment of a panel. The panel will submit its findings in the form of a written report to the Dispute Settlement Body (DSB). If the panel establishes that there was a breach of WTO law, a report shall include a recommendation for the respondent party to bring its measure into conformity with the relevant WTO agreement. The report must be adopted by the DSB which can decide not to adopt the report only by consensus. This kind of procedure is called 'reverse consensus'. If there is no appeal by the parties, the respondent party has to implement the adopted recommendation or ruling of the DSB. If immediate compliance is not possible, a reasonable period of time is given to the respondent party which then has to comply after the expiry of the implementation period. The procedure is the same in the case of an appeal, once the Appellate Body (AB) report has been adopted. If the respondent party fails to bring the measure found to be inconsistent with a relevant WTO agreement into compliance with the recommendations and rulings, the parties shall enter into negotiations to reach an agreement on compensation. If no satisfactory compensation is agreed, the complaining party may request authorisation from the DSB to adopt countermeasures, ie to apply retaliation. Countermeasures have to be applied in the same trade sector and they have to be equivalent to the level of inconsistency of the other party. If the complaining party considers that it is not practicable or effective to suspend concessions in the same trade sector, concessions could be suspended in other sectors

\footnotetext{
28 Peter Van den Bossche, The Law and Policy of the World Trade Organization: Text, Cases and Materials (CUP 2005) 71-72.

29 United States - Sections 301-310 of the Trade Act of 1974, WT/DS152/R, 22 December 1999, paras 7.78, 7.79.

30 Understanding on Rules and Procedures Governing the Settlement of Disputes in World Trade Organization (DSU) Annex 2 to the Agreement Establishing the World Trade Organization, Marrakesh, 15 April 1994.
} 
under the same WTO agreement. If this is not effective either and if the circumstances are serious enough, concessions could also be suspended under another WTO agreement. However, the fact that concessions are suspended does not end the breach of WTO law. Retaliation is considered only as a temporary measure, until the DSB ruling or recommendation is implemented by the respondent party.

\subsection{Where is the problem?}

According to what has been said above, in the case of a breach of WTO law perpetrated by the EU, the EU de facto has a choice either to comply with primary WTO obligations or to accept retaliation. The logic is that the EU will choose the more favourable and profitable option. And if that means accepting retaliation and retaining its WTO incompatible measure, the EU will retain that measure for as long as it can. So, on the one hand, the EU obtains benefits on the macro level, but on the other hand individuals who are engaged in trade in sectors in which the concessions are suspended bear the consequences for those benefits. Suspending concessions, eg increasing customs duties on exports, causes severe damage to traders. It seems that even greater injustice is done to traders if the countermeasures are not applied in the same trade sector in which the WTO inconsistent measure has been adopted. The concessions in the traders' trade sector are suspended because of a dispute between the EU and another WTO member of which they are not even aware and in a trade sector with which they have nothing to do. Consequently, traders find that the EU is responsible for the damage they suffer. After all, the conduct of the EU is the cause of the suspended concessions. Under the general principles, the party who suffers damage because of the conduct of another should be entitled to compensation. But in cases where the damage occurs due to the failure of the EU to comply with the obligations under the WTO Agreement - which is binding on the EU - things are not that simple. The fact that the EU deliberately maintains the WTO inconsistent measure and is fully aware of the consequences of this act is apparently without relevance. Individuals who suffer damage because of a breach of WTO law perpetrated by the EU have no procedural routes to complain about the illegality of the EU legislation and/or to obtain compensation. So they cannot be compensated for the damage they have already suffered and they cannot prevent further damage. Because of the denial of the direct effect of WTO law and because WTO law does not form part of the European courts' legality review, individuals cannot benefit from procedural routes which would normally be available to them if this was not a case of a breach of WTO law. ${ }^{31}$ It appears that there

31 For four procedural routes available for individuals, see above in part 2.1. 
is a lack of judicial protection for individuals that have found themselves caught in a dispute between the EU and other WTO members.

\section{Case law}

In the course of analysing whether the WTO Agreement should be granted direct effect and what the possibilities are for individuals to obtain compensation for the damage caused by a breach of WTO law, it is essential to examine the case law of the Court of Justice of the European Union. In conformity with the principles of international law, if the question of the effect of the agreement in the internal legal order is not expressly set out within the agreement, it is up to the Court to determine it. ${ }^{32}$ Since the ECJ is the body that has the final say on questions of the direct effect of the WTO Agreement and on the individual's right to damages, it is necessary to analyse the ECJ's reasoning in answering these questions. Thus, some of the most significant cases involving these issues are examined below.

\subsection{Inception - International Fruit Company}

In 1972, the International Fruit Company case ${ }^{33}$ was the first to raise the question of whether the provisions of the General Agreement on Trade and Tariffs (GATT) 1947 (and nowadays of the WTO Agreement) are capable of having direct effect. Indeed, this is where the whole saga began.

It has to be mentioned that the 'motive' to initiate this case was not the dispute between the EEC and other WTO members whose consequence would be retaliation which would damage traders. The traders found the EEC measure to be harmful to them and considered that they would be better off relying on the provision under GATT 1947. Importers of apples complained about the EEC regulation which restricted the importation of apples from third countries. They claimed that the EEC regulation was inconsistent with article XI GATT 1947 which provided for a general prohibition on quantitative trade restrictions. In order to determine whether individuals can invoke article XI GATT 1947 before the courts, the ECJ examined the spirit, the general scheme and the terms of the GATT in general. ${ }^{34}$ The Court concluded that the agreement was 'based on the principle of negotiations undertaken on the basis of reciprocal and mutually advantageous arrangements' and that its provisions were highly flexible, in particular with respect to the possibility

\footnotetext{
32 See International Fruit Company (n 15) para 19 and Kupferberg (n 9) para 17.

33 International Fruit Company (n 15).

34 ibid, paras 19, 20.
} 
of derogation and dispute settlement. ${ }^{35}$ Apparently, there was a 'lack of formalism and prevalence of political application' in the GATT $1947 .{ }^{36}$ Accordingly, the ECJ concluded that article XI GATT 1947 was not capable of conferring rights on individuals and, consequently, that the validity of the EEC regulation could not be affected by it. ${ }^{37}$ In its analysis of the capability of article XI GATT 1947 of having direct effect, the ECJ did not examine this specific provision but concluded merely on the basis of the character of the GATT 1947 as a whole. An important fact to be kept in mind is that in this case the validity of the Community measure was challenged, unlike in the following Kupferberg case ${ }^{38}$ where the scope of Community law was, by granting direct effect to the provision of the Free Trade Agreement, expanded, as pointed out above. ${ }^{39}$ So, reasonable doubt arises about whether the practical consequences of the decision 'to grant or not to grant' direct effect are the overriding factors which influence the ECJ's stance. Either way, in this case the ECJ laid foundations by setting direct effect as a 'must have' condition for a validity review in the light of international agreements and set the criteria for the test of direct effectiveness of the GATT 1947, and nowadays of the WTO Agreement, which it has since consistently applied in every case questioning the validity of EU measures in the light of the GATT 1947 or the WTO Agreement. On the other hand, the Court has on several occasions reviewed the legality of EU measures in the light of international agreements without first having established whether the international provision in question has direct effect. ${ }^{40}$

\subsection{Biret}

On 1 January 1995, the WTO Agreement entered into force and introduced some changes in comparison to the old GATT 1947 which some believed would compel the ECJ to grant direct effect to the "new and improved version'. It was expected that the ECJ would reassess the arguments given in respect of the capability of the GATT 1947 having direct effect, but the Court did not alter its stance and in each of the following cases it recalled the arguments given in International Fruit Company. ${ }^{41}$

\footnotetext{
35 ibid, para 21.

36 Patrick FJ Macrory, Arthur E Appleton, Michael G Plummer, The World Trade Organization: Legal, Economic and Political Analysis (vol 1, Springer 2005) 1485.

37 International Fruit Company (n 15) paras 27, 28.

38 Kupferberg (n 9).

39 Regarding Kupferberg, see part 2.1 above.

40 Schröder (n 11) and Case 112/80 Dürbeck v Hauptzollamt Frankfurt am Main-Flughafen [1981] ECR 1095.

41 International Fruit Company (n 15).
} 
One of these cases was Biret. ${ }^{42}$ It should also be emphasised that in Biret there was the first occurrence of the question about whether a DSB decision was capable of having direct effect.

Biret International and Établissements Biret were two French companies involved in trade in various agri-foodstuffs, in particular meat. The companies had allegedly suffered great damage after the Community adopted directives ${ }^{43}$ on the prohibition of the importation into the Community of beef and veal from farm animals to which certain substances with hormonal action had been administered. In the meantime, there was a dispute within the WTO initiated by the US and Canada ${ }^{44}$ who argued that the EC prohibition of the importation of hormone-treated meat was in breach of the SPS Agreement, ${ }^{45}$ and WTO inconsistency was found by the DSB. Biret, as well as the US and Canada, were displeased with those Community measures so they brought an action for damages under article 340 TFEU (ex article 288 TEC) before the Court of First Instance (CFI) (now the General Court (GC)), ${ }^{46}$ and after the unfavourable judgment of the CFI, brought an Appeal to the ECJ. ${ }^{47}$ They sought compensation for the damage they had allegedly suffered as a result of the adoption and continuation in force of directives which prohibited the importation into the Community of hormone-treated meat. The $\mathrm{Bi}$ ret companies were relying on the existence of a WTO decision which determined WTO inconsistency and demanded compliance with WTO obligations and since the EC had failed to implement the DSB decision, they considered that there had indeed been unlawful conduct by the EC institutions which gave rise to their right to compensation. The ECJ reiterated the conditions for the non-contractual liability of the Community, which were the illegality of the conduct of the Community institutions, actual damage and the existence of a causal link between the conduct

42 Cases C-93/02 and C-94/02 P Biret International/Établissements Biret v Council [2003] ECR I-10497.

43 Council Directive 81/602/EEC of 31 July 1981 concerning the prohibition of certain substances having a hormonal action and of any substances having a thyrostatic action [1981] OJ L222; Council Directive 88/146/EEC of 7 March 1988 prohibiting the use in livestock farming of certain substances having a hormonal action [1988] OJ L70; Council Directive 96/22/EC of 29 April 1996 concerning the prohibition on the use in stockfarming of certain substances having a hormonal or thyrostatic action and of $\beta$-agonists, and repealing Directives 81/602/EEC, 88/146/EEC and 88/299/EEC [1996] OJ, L125.

${ }_{44}$ See European Communities - Measures Concerning Meat and Meat Products (Hormones), Report of the Appellate Body, WT/DS26/AB/R, WT/DS48/AB/R, 16 January 1998.

45 Agreement on the Application of Sanitary and Phytosanitary Measures (SPS), part of annex 1A to the Agreement Establishing the World Trade Organization, Marrakesh, 15 April 1994.

46 Case T-174/00 Biret International v Council [2002] ECR II-17 and Case T-210/00 Établissements Biret v Council [2002] ECR II-47.

47 Biret (n 42). 
of the institution and the damage. ${ }^{48}$ The ECJ then confirmed the words of the CFI by stating that 'given their nature and structure, the WTO agreements are not in principle among the rules in the light of which the Court is to review the legality of measures adopted by the Community institutions'. ${ }^{49}$ So, according to the ECJ, the mere provisions of the WTO Agreement have no effect on the legality of the institutions' conduct, but it did not say the same for the DSB decision. By not defining the effect of a DSB decision, the ECJ left open the possibility that the question, about whether an individual could obtain compensation on the basis of the non-contractual liability of the EU when there was a DSB decision identifying a breach of WTO law perpetrated by the EU institutions, when the EU had failed to implement a decision and when the implementation period had expired, might in the future be answered in the positive.

\subsection{Van Parys}

However, the above question was very quickly answered in the negative. The possibility vanished with the Van Parys judgment ${ }^{50}$ where the ECJ determined the effect of the DSB decision in the EU legal order after the expiry of the implementation period. Although not determined in the context of an action for damages, the arguments that the ECJ gave here about the effect of a DSB decision have been consistently applied in all the following cases where the question of the effect of a DSB decision has been raised, irrespective of the type of action.

The Van Parys case is one of the ECJ cases which arose as a consequence of the WTO's long-lasting banana dispute which started because of the EU's overlapping international obligations. When the Agreement Establishing the World Trade Organization entered into force in 1995, the Regulation on the common organisation of the market in bananas was in force in the European Community. ${ }^{51}$ This Regulation contained preferential provisions for bananas from certain African, Caribbean and Pacific (ACP) states in accordance with the Fourth ACP-EEC Convention. ${ }^{52}$ Several WTO members, including the US, dissatisfied with such provisions, initiated a dispute settlement under the WTO, and the DSB established that certain provisions of the EC Regulation were incompatible with articles I and XIII of the General Agreement on Tariffs and Trade (GATT)

\footnotetext{
48 ibid, para 51.

49 ibid, para 52.

50 Case C-377/02 Van Parys $v$ Belgisch Interventie- en Restitutiebureau (BIRB) [2005] ECR I-1465.

51 Council Regulation (EEC) 404/93 of 13 February 1993 on the common organization of the market in bananas [1993] OJ L47/1.

52 Fourth ACP-EEC Convention signed at Lome on 15 December 1989 [1991] OJ L229/3.
} 
$1994 .{ }^{53}$ As the EC did not remove the infringement of WTO law, on the US's request, the DSB authorised the US to suspend concessions under the GATT 1994 and to levy customs duties in respect of trade originating in the Community amounting to up to USD 191.4 million per year. ${ }^{54}$

Van Parys found himself in the middle of this dispute as a trader importing bananas into the Community. He brought an action against the Belgian Intervention and Refund Board (BIRB) because of BIRB's refusal to issue him with import licences for certain quantities of bananas originating in Ecuador and Panama. Van Parys challenged the validity of the EC's Regulations ${ }^{55}$ on the common organisation of the market in bananas in the light of articles I and XIII of the GATT 1994. He claimed that BIRB's decision was unlawful because it was based on the EC Regulations which were themselves unlawful because of their inconsistency with the WTO Agreement. However, the ECJ repeated the old answer that WTO law does not in principle form part of European courts' legality review. ${ }^{56}$ As regards the effect of the DSB decision after the expiry of the implementation period, the ECJ concluded that 'even where there is a decision of the DSB holding that the measures adopted by a member are incompatible with the WTO rules, the WTO dispute settlement system nevertheless accords considerable importance to negotiation between the parties'. ${ }^{57}$ The ECJ continued several paragraphs later:

The expiry of that time-limit does not imply that the Community had exhausted the possibilities under the understanding of finding a solution to the dispute between it and the other parties. In those circumstances, to require the Community Courts, merely on the basis that that time-limit has expired, to review the lawfulness of the Community measures concerned in the light of the WTO rules, could have the effect of undermining the Community's position in its attempt to reach a mutually acceptable solution to the dispute in conformity with those rules. ${ }^{58}$

So, the Court expressly stated that the DSB decision, as well as primary WTO law, cannot be a criterion for the legality of EU measures. As an additional argument for not taking into consideration WTO law and

\footnotetext{
53 General Agreement on Tariffs and Trade (GATT), part of annex 1A to the Agreement Establishing the World Trade Organization, Marrakesh, 15 April 1994.

54 European Communities - Regime for the Importation, Sale and Distribution of Bananas (EC - Bananas III) WT/DSB/M/59.

55 Council Regulation (EC) 1637/98 of 20 July 1998 amending Regulation 404/93 on the common organization of the market in bananas [1998] OJ L210/28.

56 Van Parys (n 50) paras 38, 39.

57 ibid, para 42.

58 ibid, para 51.
} 
the DSB decision in reviewing the validity of EU law, the ECJ reiterated its reciprocity argument, emphasising that:

some of the most important commercial partners of the Community have concluded that they are not among the rules applicable by their courts when reviewing the legality of their rules of domestic law. Such lack of reciprocity would risk introducing an anomaly in the application of the WTO rules. ${ }^{59}$

So, as regards the validity of the EU measures in the light of the WTO Agreements, the existence of a DSB decision identifying a breach of WTO law, even after the expiry of the implementation period, makes no difference in the eyes of the Court.

\subsection{FIAMM and Fedon}

The FIAMM and Fedon case ${ }^{60}$ is at the core of the present case-law analysis as the most recent and most interesting one. It is the final word of the Court, for now, on the capability of substantive WTO provisions and of DSB decisions having direct effect and also on the possibility for individuals to obtain compensation on the grounds of incompatibility with WTO law. The case is also interesting because there was the first occurrence of the question about whether compensation could be obtained on grounds of non-contractual liability in the absence of unlawful conduct in the context of the EU's international obligations under the WTO. It appears that the applicants anticipated that the Court would not change its opinion on finding that there was unlawfulness in the institutions' conduct and wanted to circumvent that condition by claiming compensation for the lawful conduct of the institutions.

FIAMM and Fedon was also one of the 'bananas dispute cases'. As mentioned in the context of Van Parys, because of the inconsistency of the EC regulation on the common organisation of the market in bananas with WTO law, even after the expiry of the implementation period granted by the DSB, the US was authorised to levy customs duties in respect of trade originating in the Community amounting up to USD 191.4 million per year. ${ }^{61}$

The US did not apply these retaliatory measures in the same trade sector, ie in the bananas trade sector, but increased customs duties on import of batteries, spectacle cases, paper boxes, bed linen, bath prod-

\footnotetext{
59 ibid, para 53.

60 Joined cases C-120/06 P and 121/06 P Fabbrica italiana accumulatori motocarri Montecchio SpA (FIAMM), Fedon \&. Figli and others $v$ Council and Commission [2008] ECR I-6513.

61 See about EC - Bananas dispute in part 3.3 above.
} 
ucts, handbags, wallets, coffee makers, etc. ${ }^{62}$ Such retaliation did not affect the EC directly but severely damaged many European companies and individuals - traders importing those products into the US. Consequently, the traders considered the EC to be responsible for the damage they suffered and six actions for damages ${ }^{63}$ were brought before the Court of First Instance (CFI) from March 2000 to June 2001. The CFI delivered six judgments on 14 December 2005, all worded in a similar way, and rejecting all the claims as unfounded. ${ }^{64}$ Among these were the FIAMM case ${ }^{65}$ and the Fedon case ${ }^{66}$ which involved the greatest damage, amounting in FIAMM to EUR 10.8 million and in Fedon to EUR 2.3 million.

\subsubsection{Judgment of the $C F I^{67}$}

The applicants sought compensation under Article 288(2) TEC (now Article 340(2) TFEU) on the Community's non-contractual liability, on several grounds; firstly, they claimed that there was unlawful conduct by the EC institutions which breached WTO law and also the general principles of EC law by not bringing the EC legislation into conformity with the WTO agreements within the time limit laid down by the DSB. ${ }^{68}$ Secondly, and alternatively, the applicants sought compensation on the grounds of the non-contractual liability that had incurred even in the absence of unlawful conduct. ${ }^{69}$

As regards the liability of the Community for the unlawful conduct of its institutions, the CFI reiterated three conditions that must be satisfied in order to obtain compensation and stated that there were no grounds for finding unlawfulness of conduct. ${ }^{70}$ The CFI supported this stance with several standard arguments, namely the fact that some

\footnotetext{
62 See Notice of the United States Trade Representative (USTR), Federal Register, vol 64, issue 7419209 (19 April 1999).

63 Cases T-69/00 FIAMM and FIAMM Technologies $v$ Council and Commission [2005] ECR II-5393; T-151/00 Le Laboratoire du Bain v Council and Commission [2005] ECR II-23; T301/00 Groupe Fremaux SA and Palais Royal Inc $v$ Council and Commission [2005] ECR II-25; T-320/00 CD Cartondruck $A D v$ Council and Commission [2005] ECR II-27; T-383/00 Beamglow Ltd $v$ EP, Council and Commission [2005] ECR II-5459; T-135/01 Giorgio Fedon \& Figli SpA, Fedon Srl and Fedon America USA Inc $v$ Council and Commission [2005] ECR II-29.

64 FIAMM (n 63); Le Laboratoire du Bain (n 63); Groupe Fremaux and Palais Royal (n 63); Cartondruck (n 63); Beamglow (n 63); Fedon (n 63).

65 FIAMM (n 63).

66 Fedon (n 63).

67 As regards the judgment of the CFI, for the sake of clarity, only the paragraphs from the FIAMM case are cited.

68 FIAMM (n 63) paras 69, 84, 92-95.

69 ibid, para 84.

70 ibid, paras 85, 108-110, 113.
} 
of the most important commercial partners of the Community did not grant the WTO Agreement direct effect, ie the reciprocity argument, the importance of negotiations and the possibility of depriving the legislative or executive organs of the Community of the scope for manoeuvre. ${ }^{71}$ The applicants' claim that the DSB decision met all the conditions for direct effect $^{72}$ was also declared as unfounded because, according to the CFI, even after the expiry of the implementation period, considerable importance is still accorded to negotiation, and the methods for settling disputes made available by the DSU had not been exhausted. Therefore, in such a case there was also the possibility of depriving the legislative or executive organs of the Community of the scope for manoeuvre. ${ }^{73}$ The applicants also claimed that, by not bringing the EC legislation into conformity with the WTO agreements within the time limit laid down by the DSB, the EC institutions were not only in breach of WTO law but also in breach of certain fundamental principles of Community law, including the principles of the protection of legitimate expectations and of legal certainty, the principles of the right to property and the pursuit of an economic activity, and the principle of proper administration. ${ }^{74}$ The CFI did not enter into a detailed analysis concerning whether those principles were in fact breached, but gave a simple answer that all the complaints 'rest on the premise that the conduct of which the defendant institutions are accused is contrary to WTO rules'. ${ }^{75}$ Consequently, since there was no unlawful conduct of the EC institutions, the CFI dismissed the applicants' claim for compensation grounded on the non-contractual liability of the Community for unlawful conduct. ${ }^{76}$

As regards the applicants' alternative claim, the liability of the Community in the absence of unlawful conduct of its institutions, the CFI confirmed the possibility that the Community may incur non-contractual liability even for its lawful acts. ${ }^{77}$ The CFI referred to the ECJ De Boer Buizen judgment ${ }^{78}$ and stated that:

Where, as in the present case, it has not been established that conduct attributed to the Community institutions is unlawful, that does not mean that undertakings which, as a category of economic operators, are required to bear a disproportionate part of the burden

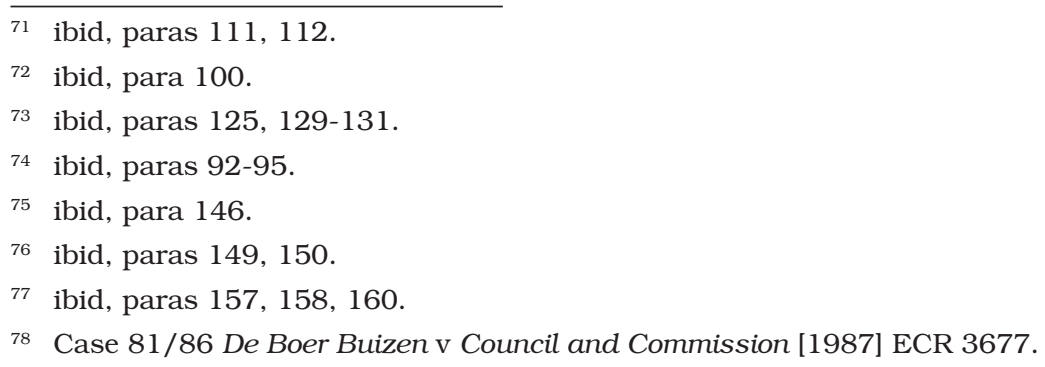


resulting from a restriction of access to export markets can in no circumstances obtain compensation by virtue of the Community's non-contractual liability. ${ }^{79}$

The CFI pointed out that the 'general principles common to the laws of the Member States' within the meaning of article 288(2) TEC (now article 340(2) TFEU) include not only liability for unlawful acts since national laws, in certain cases, allow individuals to obtain compensation even in the absence of unlawful action by the perpetrator of the damage'. ${ }^{80}$ The CFI then reiterated the conditions that must be satisfied in order for the Community to incur non-contractual liability in the absence of unlawful conduct, which the ECJ had put forward in its Dorsch judgment, ${ }^{81}$ namely the occurrence of actual damage, the causal link between that damage and the conduct of the Community institution and the unusual and special nature of the damage. ${ }^{82}$ In its course of analysis, the CFI concluded that the conditions of actual and certain damage and of direct causal link were satisfied. ${ }^{83}$ It concluded that there was a sufficiently direct causal nexus between the conduct of the Community institutions and the damage, irrespective of the fact that the increased customs duty was imposed by the unilateral decision of the United States. ${ }^{84}$ As for the unusual and special nature of the damage suffered, the CFI recalled its previous case law, considering the damage to be unusual 'when it exceeds the limits of the economic risks inherent in operating in the sector concerned' and special 'when it affects a particular circle of economic operators in a disproportionate manner by comparison with other operators'. ${ }^{85}$ The CFI did not consider the damage which occurred to the traders in batteries as a consequence of the dispute over bananas to be unusual. ${ }^{86}$ On the contrary, it considered it to be the risk inherent in traders' export operations and stated that:

The possibility of tariff concessions being suspended as provided for by the WTO agreements is among the vicissitudes inherent in the current system of international trade. Accordingly, the risk of this vicissitude has to be borne by every operator who decides to sell his products on the market of one of the WTO members [especially since] it is clear from the DSU, which was publicised appropriately

\footnotetext{
79 FIAMM (n 63) para 157.

80 ibid, paras 158, 159.

81 Case C-237/98 P Dorsch Consult v Council and Commission [2000] ECR I-4549.

82 FIAMM (n 63) para 160.

83 ibid, paras 170, 191.

84 ibid, para 184.

85 ibid, para 202.

86 ibid, paras 203, 211.
} 
so as to ensure that Community operators were aware of it, that the complaining member of the WTO may seek to suspend concessions or other obligations in sectors other than that in which the panel or Appellate Body has found a violation. ${ }^{87}$

The CFI concluded that the applicants' claim for compensation on grounds of non-contractual liability in the absence of unlawful conduct was also unfounded. ${ }^{88}$

Analysing the Court's reasoning, the question arises about whether suspending concessions by the complaining WTO member, in a sector other than that in which the dispute occurred, could really be considered a normal risk for an international trader? Should traders really be aware of such a risk, that a dispute over bananas could negatively affect their trade in batteries and spectacle cases? It is true that the explicit rules of the World Trade Organization allow for such a possibility. Nevertheless, does the fact that it is published make it fair and justifiable to affect traders who have nothing to do with the dispute? Is it not an act of discrimination to randomly select a small fraction of international traders and place the entire burden on them? Why them and not some other trade sector? Either way, the CFI put forward its opinion, from which it appears that engaging in international trade under the WTO system is a very risky business.

\subsubsection{Judgment of the ECJ}

The ECJ confirmed the ruling of the CFI that the claims for compensation were unfounded..$^{89}$ It confirmed that compensation could not be obtained on the grounds of the unlawful conduct of the institutions. ${ }^{90}$ In addition, the ECJ emphasised that there was no basis for the distinction between the substantive provisions of WTO law and the DSB decision as regards the capability of having direct effect and stated that:

A recommendation or a ruling of the DSB finding that the substantive rules contained in the WTO agreements have not been complied with is, whatever the precise legal effect attaching to such a recommendation or ruling, no more capable than those rules of conferring upon individuals a right to rely thereon before the Community courts for the purpose of having the legality of the conduct of the Community institutions reviewed. ${ }^{91}$

87 ibid, paras 205, 207-209.

88 ibid, paras 212, 213.

89 FIAMM and Fedon (n 60) paras 104, 133, 134, 188, 189.

90 ibid, paras 104, 133, 134.

91 ibid, paras 126, 128-131. 
However, the ECJ criticised the words of the CFI on the possibility for the EC to incur non-contractual liability in the absence of unlawful conduct and stated that in that regard the CFI had erred in law. ${ }^{92}$ The ECJ stated that in the Dorsch judgment ${ }^{93}$ the Court had presented the conditions for such liability only in a hypothetical way.$^{94}$ Thus, the question put forward above, whether the possibility of suspending concessions by the complaining WTO member, in a sector other than that in which the dispute occurred, is a normal risk for an international trader, seems (at least for now) superfluous. In order to eliminate every doubt, the ECJ explained what is implied, in accordance with the settled case law, under 'the general principles common to the laws of the Member States' within the meaning of article 288(2) TEC (now article 340(2) TFEU) ${ }^{95}$ It pointed out that, in order to incur liability, there must be unlawfulness of conduct ${ }^{96}$ Finally, the ECJ concluded that:

No liability regime exists under which the Community can incur liability for conduct falling within the sphere of its legislative competence in a situation where any failure of such conduct to comply with the WTO agreements cannot be relied upon before the Community courts. ${ }^{97}$

It should also be mentioned that it seems that the ECJ implicitly said to international traders that they have nothing to complain of and no reason to seek compensation from the EC, as economic activity carries with it certain risks and the trader must be aware of the risk that the complaining WTO member could pick exactly their trade sector to apply retaliatory measures..$^{98}$ So the ECJ excluded, at least in the present circumstances, the only hope for traders to obtain compensation - noncontractual liability in the absence of unlawful conduct. It also seems that it has no intention of changing its mind and giving compensation on any grounds whatsoever.

\subsection{Arran Aromatics - waiting in vain}

Arran Aromatics ${ }^{99}$ was also one of the 'bananas dispute cases'. In 2003, Arran Aromatics Limited, Mr Iain Russel and Mr Allastair Ren-

\footnotetext{
92 ibid, para 179.

93 Dorsch (n 81) paras 18, 19.

94 FIAMM and Fedon (n 60) paras 168, 169.

95 ibid, para 164.

96 ibid, para 164.

97 ibid, para 176.

98 ibid, paras 185, 186.

99 Case T-109/03: Action brought on 28 March 2003 by Arran Aromatics Limited, Mr Iain Russel and Mr Allastair Rennick against the Commission of the European Communities (Notification of action OJ 2003, C-135/33); and the Order of the CFI brought on 13 July 2006 on removal from the Register.
} 
nick brought an action against the Commission before the CFI. ${ }^{100}$ The first applicant is a Scottish company which produces bath products, a large proportion of it exported to the US, and the other two applicants are officials of that company. The applicants claimed compensation under article 288(2) TEC (now article 340(2 TFEU)) on non-contractual liability. ${ }^{101}$ Here, the applicants sought compensation on grounds of a breach of Community law, ie the fundamental principles of the EC, and not on grounds of a breach of WTO law. ${ }^{102}$ They claimed that the institutions' conduct, not complying with its obligations under the WTO, 'violates the freedom to pursue a trade or business, the principle of proportionality, the principle of non-discrimination and finally the principle of good faith in international law and the legitimate expectations traders can derive from that'. ${ }^{103}$ As a consequence of the EC not complying with its international obligations, the US increased customs duty on bath preparations because of which the company allegedly suffered serious material damage and the two individuals suffered non-material damage due to stress and anxiety. ${ }^{104}$ It would be interesting to see what the Court would have ruled in this case, but unfortunately the applicants withdrew from the case in 2006. ${ }^{105}$ Apparently, they realised that the Court was firmly holding its stance and that they would obtain nothing but the high costs of the proceedings.

Perhaps in some of the cases to come, the Court will change its mind, but from what has so far been presented it seems that a change in the Court's stance is not to be expected soon. For now, we can merely draw conclusions on the lack of legal protection for the individuals-international traders who were not lucky enough to be in a trade sector not chosen by the complaining WTO member for the purpose of retaliation.

\section{Alternative routes - substitutes for direct effect?}

The fact remains that the WTO Agreement has no direct effect in the EU legal order and, consequently, individuals cannot rely on its provisions before the EU courts. Still, it is not true that WTO law in the EU legal order has no effect at all. On the contrary, it has an effect on EU law that is not insignificant. There is still a way, albeit a very limited one, for private litigants to benefit from the WTO provisions, irrespective of the

\footnotetext{
100 Arran Aromatics, Notification of action (n 99).

101 ibid.

102 ibid.

103 ibid.

104 ibid.

105 Arran Aromatics, Order of the CFI on removal from the Register (n 99).
} 
fact that they cannot invoke those provisions. Consequently, it is necessary to briefly analyse the forms of indirect effect that the WTO agreement has in the EU legal order.

\subsection{Fediol and Nakajima}

In the Fediol ${ }^{106}$ and Nakajima ${ }^{107}$ cases, the ECJ established a principle which is, according to the Court, an exception to the general rule and under which the WTO Agreement could be granted direct effect. ${ }^{108}$ In Fediol, the applicant brought an action for the annulment of the Commission's decision rejecting its request to initiate an examination procedure in respect of certain illicit commercial practices of Argentina under Council Regulation No 2641/84. ${ }^{109}$ That Regulation allowed the Commission to investigate third country trade practices which were incompatible with international law or with the generally accepted rules. ${ }^{110}$ The ECJ concluded that since 'the GATT provisions form part of the rules of international law to which Article 2(1) of that regulation refers', it could review the legality of the contested decision in the light of the GATT $1947 .{ }^{111}$ In the Nakajima case, the applicant challenged the EEC Anti-Dumping Regulation as incompatible with the GATT 1947, more precisely, with the GATT Anti-Dumping Code. ${ }^{112}$ The ECJ ruled that here, too, it could review the legality of the Community regulation because

the Community regulation was adopted in order to comply with the international obligations of the Community, which, as the Court has consistently held, is therefore under an obligation to ensure compliance with the General Agreement and its implementing measures. ${ }^{113}$

So, in these cases the ECJ established a principle under which the legality of the EU measure can be reviewed in the light of the GATT 1947 and now in respect of the WTO Agreement

only if the Community intended to implement a particular obligation entered into within the framework of GATT, or if the Community act expressly refers to specific provisions of GATT. ${ }^{114}$

\footnotetext{
106 Case 70/87 Fediol v Commission [1989] ECR 1781.

107 Case C-69/89 Nakajima v Council [1991] ECR I-2069.

108 FIAMM (n 63) paras 114, 115; FIAMM and Fedon (n 60) paras 47, 48.

109 Fediol (n 106) para 1; Council Regulation (EEC) 2641/84 of 17 September 1984 [1984] OJ L252.

110 Council Regulation (n 109) art 2(1).

111 Fediol (n 106) paras 19-22.

112 Nakajima (n 107) paras 1, 26; Council Regulation (EEC) No 3651/88 of 23 November 1988 [1988] OJ L317.

113 Nakajima (n 107) paras 30-32.

114 Case C-280/93 Germany v Council [1994] ECR I-4973, para 111 (emphasis added).
} 
According to the Court, this is an exception where provisions of the WTO law have direct effect. ${ }^{115}$ However, it seems that this is not the case of an 'exception' where direct effect is granted. ${ }^{116}$ How can it be called direct effect when the possibility of a WTO provision being invoked depends on the existence of a certain EU provision? Individuals cannot directly invoke WTO provisions before the courts, but only if an EU measure enables them to do so. Therefore this principle cannot be considered as direct effect if direct effect means the ability of a provision of an international agreement to be invoked by individuals before EU courts entirely independently of EU law. ${ }^{117}$

\subsection{Consistent interpretation}

The principle of consistent interpretation implies interpreting EU law as far as possible in conformity with the provisions of the WTO Agreement. The ECJ has acknowledged that the WTO provisions are capable of having such influence on the EU legal order and that it has the obligation of consistent interpretation as regards WTO law. ${ }^{118}$ Thus, the ECJ has stated that:

It is settled case-law that the primacy of international agreements concluded by the Community over secondary Community legislation requires that the latter be interpreted, in so far as is possible, in conformity with those agreements. ${ }^{19}$

However, this principle has limited applicability: EU legislation to be interpreted must exist and it must be sufficiently flexible for the interpretation. There must also be no conflict between the provision of an international agreement and the EU provision which is interpreted, ie the interpretation cannot go contra legem. Thus, individuals who claim that inconsistency exists between the EU measure and international obligations under the WTO and claim compensation for damage which has occurred to them as a consequence of a breach of WTO law perpetrated by the EU cannot benefit from this principle.

The question arises about whether those available 'alternatives' are sufficient to protect individuals. The answer appears to be negative. The

\footnotetext{
115 FIAMM (n 63) paras 114, 115; FIAMM and Fedon (n 60) paras 47, 48.

116 See also Pieter Jan Kuijper and Marco Bronckers, 'WTO Law in the European Court of Justice' (2005) 42 CML Rev 1324-1325; Piet Eeckhout, External Relations of the European Union, Legal and Constitutional Foundations, (OUP 2005) 318.

117 For the concept of 'direct effect', see in part 2 above.

118 Case C-61/94 Commission v Germany [1996] ECR I-3989, para 52; Case C-335/05 Řizení Letového Provozu ČR, sp v Bundesamt für Finanzen [2007] ECR I-4307, para 16.

119 Commission v Germany (n 118) para 52; Ǩizení Letového Provozu (n 118) para 16.
} 
Fediol and Nakajima principle has been rarely applied by the Court as it includes strict conditions that need to be satisfied, and the principle of consistent interpretation cannot be applied in the case of a conflict of laws. So, the inevitable conclusion is that those available alternatives compensating the lack of direct effect of the WTO Agreement are not sufficient to protect individuals that have found themselves in the middle of a dispute between the EU and other WTO members. Therefore, there is a need to find a satisfactory solution that is acceptable from the standpoint of the EU institutions and that at the same time provides a sufficient level of protection for individuals.

\section{Giving direct effect to WTO law - is this a good idea?}

Individuals who suffered damage which occurred as a consequence of a breach of WTO law perpetrated by the EU consider that granting direct effect to WTO law would be a solution to their problems and from 1972 have been stubbornly trying to convince the ECJ that the WTO Agreement is capable of having direct effect. On the other hand, the ECJ has been equally stubborn in denying direct effect and repeating the same reasons for such a decision in all its judgments. It is likely that private persons would benefit from the possibility of relying on the provisions of WTO law, but the question arises about what kind of impact this would have on the EU institutions and the EU in general? Could it harm the EU and if it had some negative consequences, would the benefit outweigh the costs? Thus, it is necessary to analyse the arguments for and against granting direct effect and to try to predict the consequences that would arise. Would this be a satisfactory solution for everyone?

\subsection{The arguments for}

Giving direct effect to the WTO Agreement would certainly make life easier for individuals who find its provisions more favourable for their trade than the provisions provided under EU secondary law. It would also be a 'lifebelt' for individuals who have suffered damage from retaliation which was a consequence of the EU's deliberate maintenance of WTO inconsistent measures. If the WTO Agreement was granted direct effect, individuals could invoke its provisions before national and EU courts and could benefit from the generally available procedural routes. ${ }^{120}$ Thus, they could request the Court to review the legality of EU secondary legislation in the light of the WTO Agreement which would annul the unlawful measure or grant compensation due to unlawfulness, depending on the

$\overline{120}$ About the four procedural routes available for individuals, see in part 2.1 above. 
type of action initiated. ${ }^{121}$ So, the main argument in favour of the idea of granting direct effect is the argument of judicial protection, which, after all, is the principal purpose of the concept of direct effect. According to some advocates of direct effect, if individuals could rely on the provisions of the WTO Agreement, an individual's right to trade freely with foreigners would be judicially protected and enforced. ${ }^{122}$ In addition, if the WTO provisions were thus protected by national and EU courts, their enforceability and effectiveness would be significantly increased because WTO members would have less possibility for noncompliance. Consequently, disputes between WTO members would often be prevented. ${ }^{123}$

\subsection{Arguments against}

On the other hand, giving direct effect to WTO law would also have some negative consequences. As described above, according to the DSU, after the adoption of a DSB decision establishing that there was a breach of WTO law, the respondent party has the obligation to implement it, at the latest after the expiry of the implementation period. ${ }^{124}$ However, the EU, as a respondent party, still de facto has the choice not to implement the DSB decision and withdraw its unlawful measure, but to enter into negotiations to reach a mutually acceptable agreement on compensation. ${ }^{125}$ If such an agreement cannot be reached, retaliation ${ }^{126}$ follows whose burden is borne by individuals and not by the EU itself. If the WTO Agreement had direct effect in the EU legal order, individuals could immediately, at the first sign of any inconsistency of EU secondary legislation with the WTO Agreement, bring an action claiming such unlawfulness before a national or EU court. The EU court would then, in the event of finding inconsistency with WTO law, have to annul the EU measure in question. Thus, the EU would be compelled by its own courts to comply with WTO law. The EU therefore might be compelled to comply with its obligations under the WTO even before the dispute has been initiated. In addition, if the dispute were initiated, the EU might not have a chance to continue with the dispute settlement procedure and to negotiate for itself a solution that would be more favourable than simply complying with primary WTO law. It could not maintain its 'unlawful'

\footnotetext{
121 See in part 2.1 above.

122 Peter van den Bossche, The Law and Policy of the World Trade Organization: Text, Cases and Materials (CUP 2008) 67.

123 van den Bossche (n122) 66.

124 Regarding the WTO dispute settlement procedure, see in part 2.2 above; see also DSU (n 30) art 22.

125 See in part 2.2 above; see also DSU (n 30) art 22.

126 See DSU (n 30) art 22.
} 
measure from which it benefits and along with that suffer less harm from the negotiated compensation than it would from the withdrawal of its measure, even if only temporarily. It is true that the final resolution of the dispute must be in accordance with the WTO provisions, ie the WTO inconsistent measure must be withdrawn, ${ }^{127}$ but the EU has some benefit in this between-period, otherwise it would not delay complying with WTO law. Thus, it seems that the ECJ is right in pointing out that giving direct effect to the WTO Agreement would deprive the legislative and executive organs of their scope for manoeuvre. ${ }^{128}$ As pointed out above, the EU institutions have a certain scope for manoeuvre even after the DSB decision is adopted because they can still reach a mutually acceptable solution to the dispute. Granting direct effect carries the risk of depriving them of rights granted under article 22 DSU. It seems that the Court's flexibility argument is really a valid one.

The second main argument against granting direct effect, which is tightly connected with the first, is the reciprocity argument. It is legal reality that most WTO Member States have not granted WTO law direct effect in their legal order, among whom are the United States, Canada, Japan and China - some of the EU's most important trading partners. ${ }^{129}$ If the EU granted direct effect to WTO law, its legislative and executive organs would be deprived of the scope for manoeuvre, while the legislative and executive organs of its major trading partners would still preserve such scope. The EU would thus weakened its position within the World Trade Organization and be at a disadvantage compared with its trading partners. As AG Maduro rightly pointed out, it would undeniably jeopardise the political freedom of the EU. ${ }^{130}$ In addition, other WTO members and foreign traders could rely on the provisions of the WTO Agreement within the EU, but the EU and its traders could not rely on it before the courts of those member states. Granting direct effect in the EU legal order would thus result in the unbalanced application of WTO rules.

So, the ECJ, influenced by these arguments, has exercised 'judicial self-restraint' in order not to deprive the legislative and executive organs of the EU of the right granted to them under the WTO. ${ }^{131}$ Thus, the ECJ has delivered a ruling mainly influenced by political and economic considerations. However, it appears that the ruling on the direct effect of the

\footnotetext{
127 See DSU (n 30) art 22.

128 FIAMM and Fedon (n 60) paras 117-119.

129 Van den Bossche (n 28) 71-72.

130 FIAMM and Fedon (n 60), Opinion of AG Maduro, para 49.

131 Gráinne de Búrca and Joanne Scott, The EU and the WTO: Legal and Constitutional Issues (Hart Publishing 2001) 115.
} 
WTO Agreement, due to the nature of the WTO system, cannot be made without taking into account those considerations. Therefore, it only remains to conclude that the Court has made the right decision not to grant direct effect and that giving direct effect to WTO law in the present circumstances would probably not be a good idea.

\section{Best possible solution? - for now}

If giving direct effect to the WTO Agreement is not a good idea and a satisfactory solution for both sides - individuals and EU institutions - what is? Something still needs to be done. It seems highly unjust to allow a small fraction of traders to bear the entire burden arising from the EU's desire to achieve its best interest in international trade relations and not to provide those individuals with procedural routes for the legal protection of their interest. There is a need to find a solution acceptable from the standpoint of the EU institutions and at the same time one that would provide a sufficient level of protection for individuals. Perhaps some of the positive effects that granting direct effect has could be obtained through some other solution which would not negatively affect the EU in general, ie which would not deprive the EU institutions of their scope for manoeuvre under the WTO.

Among numerous solutions proposed by various scholars, the recognition of no-fault liability seems the most appropriate solution in the present circumstances. Individuals who have suffered damage because they were affected by the retaliation of a complaining WTO member would obtain compensation under article 340(2) TFEU on non-contractual liability. Such liability could be recognised as being among the 'general principles common to the laws of the Member States'. It is true that no-fault liability is not a recognised legal principle in all the Member States, ${ }^{132}$ but, as AG Maduro pointed out, 'even a solution adopted by a minority may be preferred if it best meets the requirements of the Community system'. ${ }^{133}$ AG Maduro, as a great supporter of this kind of solution, stated that the 'mathematical logic of the lowest common denominator' would not lead to a satisfactory solution regarding legal protection of individuals. ${ }^{134} \mathrm{He}$ also referred to the opinion of AG Roemer who also considers that the 'rule of the lowest limit', ie adopting only rules existing in all the Member States, is not the best method. ${ }^{135}$ Therefore, the EU courts should rely on national law but not be bound by it, and the most

\footnotetext{
132 See von Bar (n 22).

133 Opinion of AG Maduro (n 130) para 55.

134 ibid, para 55

135 ibid, para 55; Case 5/71 Zuckerfabrik Schöppenstedt v Council [1971] ECR 975, Opinion of AG Roemer, especially 989.
} 
appropriate solution for the EU legal order should be adopted. And nofault liability, in the present circumstances, seems the best option. The ECJ has already considered such a possibility, in a hypothetical way, and established conditions that need to be satisfied for compensation to be obtained, namely the occurrence of actual damage, the causal link between that damage and the conduct of the Community institution, and the unusual and special nature of the damage. ${ }^{136}$ Maduro agreed with the Court that damage is unusual when it exceeds the risk inherent in operating in the sector concerned, but added that it also has to 'entail sufficiently serious harm to the attributes of the right to property'. ${ }^{137}$ Damage is of a special nature, as defined by the court, "when it affects a particular circle of economic operators in a disproportionate manner by comparison with other operators'. ${ }^{138}$ The requirement of the special nature of the damage, in a situation where a small fraction of traders from the EU is chosen to bear the entire burden of the retaliation, should not be controversial. As regards the unusual nature of the damage, the circumstance of retaliation being applied in a sector other than that in which the dispute occurred cannot be considered a normal risk for an international trader. Why should a trader operating, for example, with batteries and spectacle cases be aware of some kind of dispute over bananas, or any other fruit? As AG Maduro rightly pointed out, the damage is unusual

where there is no link between the act or conduct causing the damage and the economic sector in which the undertakings suffering the damage operate. In the absence of such a link, the damage cannot be regarded as the manifestation of a normal commercial risk against which a prudent operator could and should have protected himself. ${ }^{139}$

Maduro also added that only EU citizens should rely on this liability system, so as not to disregard the principle of reciprocity. ${ }^{140}$ Thus, the principle of no-fault liability would provide judicial protection to individuals who have suffered great damage as they unfortunately found themselves in the middle of a dispute between the EU and other WTO member and ended up as incidental victims. On the other hand, EU institutions should not be dissatisfied with this kind of solution - due to the fact that if no unlawfulness is established, their scope for manoeuvre under the WTO system would be preserved. The EU could maintain its 'unlawful'

\footnotetext{
136 Dorsch (n 81) paras 18, 19; FIAMM and Fedon (n 60) paras 168, 169. 
measure for a certain period of time and it could enter into further negotiations in order to reach a 'mutually acceptable solution'. An additional argument in favour of the establishment of no-fault liability is that it would increase good governance by forcing the EU institutions to better assess the costs that would occur for individuals and the advantage that would result for the sector in which the unlawful measures were maintained. ${ }^{141}$ It would also give rise to the principle of equality of citizens in bearing public burdens, as it would leave it to the EU 'to decide whether that cost must be borne solely by the undertakings affected by such measures or distributed over society in general.' ${ }^{142}$

Thus, the conclusion can be drawn that establishing a no-fault liability regime would resolve the burning issue of lack of judicial protection. It would not, of course, be a satisfactory solution for everyone. Individuals who find that they would be better off relying on the WTO provisions than on EU secondary law and who seek to invoke the WTO Agreement before the court would certainly not be satisfied with this kind of solution. However, given the circumstances of the WTO system, it seems that it is not possible to offer such a solution for now. On the other hand, this is a solution which would be acceptable to individuals who have suffered damage caused by retaliation. It would also be acceptable to EU institutions.

\section{Conclusion}

Although, according to the provisions of the Treaty on the Functioning of the European Union and ECJ case law, all international agreements concluded by the EU are binding upon the EU and its institutions and form an integral part of Union's legal order, in fact different international agreements have a different legal status in the EU legal order. If not settled within the agreement, it is up to the ECJ to determine whether the international agreement in question has direct effect. As regards the WTO Agreement, the ECJ firmly holds its position that due to its nature and structure the WTO Agreement is not capable of having direct effect and does not in principle form part of the European courts' legality review. So, an individual, or any other legal subject, cannot invoke the provision of a WTO Agreement before a national or EU court in order to seek the annulment of a WTO inconsistent measure or to seek compensation for the damage caused as a result of a breach of WTO law perpetrated by the EU. Due to this inability to invoke the provisions of WTO law, there is a lack of judicial protection for traders who count in

\footnotetext{
141 ibid, para 59.

142 ibid, paras 60, 62.
} 
their international operations on the rights granted to them under the WTO. It seems especially that a great injustice is done in a situation where the EU, when 'resolving' a dispute with another WTO member, deliberately chooses the option of retaliation whose consequences are suffered by the traders in a trade sector randomly chosen by the other WTO member. There are some alternative routes for individuals to benefit from WTO law, namely the Fediol and Nakajima principle, and the principle of consistent interpretation, but they alone are not sufficient to protect traders who have found themselves in the middle of a dispute between the EU and other WTO members. Therefore, there is a need to find a satisfactory solution acceptable from the standpoint of EU institutions and at the same time one that would provide a sufficient level of protection for individuals. It seems that granting direct effect to the WTO Agreement would not be that 'satisfactory solution'. After analysing the possibility of granting direct effect to WTO law, the conclusion arises that it would have negative consequences for the EU in general. The EU would have its position weakened within the World Trade Organization and would be at a disadvantage compared with its trading partners. However, establishing a no-fault liability regime would likely resolve the burning issue of lack of judicial protection. It would provide compensation to traders who have suffered damage as a result of retaliation and would give rise to the principle of equality of citizens in bearing public burdens while leaving the EU's political freedom intact. Time will tell whether the ECJ will resolve this issue by choosing this kind of 'solution'. As regards the direct effect of the WTO Agreement, given the firm stance of the ECJ for so many years and the present circumstances in the World Trade Organization, it is unlikely that the ruling of the Court will change in the near future. 